\title{
Model Probabilitas Alih Moda Sepeda Motor ke Angkutan Kota di Kecamatan Bekasi Timur
}

\author{
Ginanjar Prayogo dan Ketut Dewi Martha Erli Handayeni \\ Jurusan Perencanaan Wilayah Dan Kota, Fakultas Teknik Sipil dan Perencanaan, \\ Institut Teknologi Sepuluh Nopember (ITS) \\ Jl. Arief Rahman Hakim, Surabaya 60111 Indonesia \\ e-mail: erli.martha@gmail.com
}

\begin{abstract}
Abstrak-Keberadaan angkutan kota yang kurang diminati pelaku pergerakan memicu peningkatan penggunaan kendaraan pribadi khususnya sepeda motor. Share penggunaan angkutan kota di Kota Bekasi berada pada kisaran $24 \%$ dan $76 \%$ pengguna kendaraan pribadi dengan komposisi dominasi sepeda motor sebesar $64 \%$ dan $20 \%$ pengguna mobil sisanya berupa kendaraan lainnya. Tingginya angka pengguna kendaraan pribadi terjadi karena kurang optimalnya fungsi angkutan kota sebagai moda pemenuh kebutuhan transportasi. Dengan kondisi tersebut mengakibatkan dominasi kendaraan pribadi khususnya sepeda motor yang berdampak pada kemacetan jalan akibat kepadatan kendaraan. Penelitian ini bertujuan untuk merumuskan model probabilitas pemilihan moda antara sepeda motor dan angkutan kota, yang dilakukan melalui identifikasi kondisi eksisting sepeda motor dan angkutan kota berdasarkan atribut pelayanannya, selanjutnya diolah menggunakan teknik regresi logistik biner. Hasil analaisis menunjukkan bahwa probabilitas pemilihan moda eksisting di Kecamatan Bekasi Timur hanya sebesar $0.003 \%$ penggunaan angkutan kota dan $99.997 \%$ penggunaan sepeda motor. Probabilitas alih moda ke angkutan kota dapat ditingkatkan dengan meningkatkan keamanan, waktu tunggu, waktu tempuh, dan kenyamanan angkutan kota.
\end{abstract}

Kata Kunci_-Angkutan kota, logit biner, pilihan moda, sepeda motor

\section{PENDAHULUAN}

$\mathrm{T}$ RANSPORTASI adalah usaha pemindahan atau pergerakan orang maupun barang dari lokasi asal ke lokasi tujuan untuk keperluan tertentu dengan mempergunakan moda transportasi tertentu [1]. Transportasi merupakan urat nadi kehidupan sehari-hari dan salah satu kebutuhan pokok masyarakat. Hampir setiap orang memerlukan transportasi untuk memenuhi kebutuhan hidupnya seperti kebutuhan untuk bekerja, sekolah, rekreasi, maupun berinteraksi sosial. Hal ini karena setiap pergerakan yang dilakukan oleh masyarakat tidak dapat dipenuhi di satu tempat sehingga masyarakat perlu pergi ke suatu tempat yang berbeda untuk dapat memenuhi kebutuhan hidupnya dengan menggunakan alat transportasi. Adanya kebutuhan aktivitas tersebut pada akhirnya mendorong seseorang untuk memilih moda yang digunakan.

Salah satu permasalahan yang dihadapi adalah supply transportasi masih berbanding terbalik dengan demand yang cukup tinggi, seperti penyediaan sarana transportasi umum maupun prasarana jalan yang tidak seimbang dengan pertumbuhan penduduk. Kecenderungan akan tindakan individual untuk memenuhi kebutuhan pergerakan yang meningkat seiring dengan pertumbuhan penduduk merupakan suatu bentuk ketidakpuasaan akan supply transportasi yang ada pun semakin tinggi. Hal ini menyebabkan kemacetan, tundaan, kecelakaan, gangguan kesehatan, hingga permasalahan lingkungan. Permasalahan yang sama juga terjadi di Kota Bekasi.

Tidak dapat dipungkiri sebagai kota penyangga Ibukota, Kota Bekasi, terjadi konsentrasi aktivitas baik pergerakan internal maupun pergerakan eksternal. Berdasarkan data yang diperoleh [2], bahwa share penggunaan kendaraan masih didominasi oleh kendaraan pribadi sebesar $76 \%$ dan angkutan kota sebesar $24 \%$. Kendaraan pribadi tersebut mayoritas berupa kendaraan roda dua atau sepeda motor sebesar 64\%, mobil sebesar 20\%, dan sisanya berupa kendaraan bak baik terbuka maupun tertutup.

Kecamatan Bekasi Timur merupakan salah satu kecamatan dengan kepadatan tertinggi di Kota Bekasi dengan jumlah penduduk sebesar 257.265 jiwa namun memiliki luas wilayah paling kecil sebesar $12,78 \mathrm{~km}^{2}$ dengan kepadatan mencapai 16538 jiwa $/ \mathrm{km}^{2}$. Kecamatan Bekasi Timur dibagi menjadi empat wilayah kelurahan, diantaranya Kelurahan Margahayu dengan jumlah Kepala Keluarga sebesar 14.540 KK, Keluarahan Bekasi Jaya dengan jumlah KK sebesar 14.230 KK, Kelurahan, Aren Jaya dengan 13.762 KK, dan Kelurahan Duren Jaya 14.135 KK. Dengan luasan dan jumlah penduduk tersebut, Kecamatan Bekasi Timur merupakan Kecamatan dengan kepadatan penduduk terbesar sebesar 18.603 jiwa/km2 [3]. Terlebih lagi Kecamatan Bekasi Timur merupakan kawasan hunian dengan kepadatan tinggi dan memiliki kelemahan sebagai kawasan bangkitan tertinggi di Kota Bekasi [2].

Kondisi ini tidak diimbangi dengan sistem transportasi yang baik, beberapa ruas jalan yang terdapat di Kecamatan Bekasi timur diantaranya adalah Jalan Cut Mutia dan Jalan Juanda yang merupakan jalan arteri primer memiliki nilai Level of Service $(L o S)$ E pada peak hour. Sedangkan untuk Jalan Chairil Anwar dan Jalan Pahlawan yang merupakan jalan arteri sekunder memiliki nilai $L o S$ pada peak hour E dan masih banyak jalan di Kecamatan Bekasi Timur yang memiliki nilai LoS E yaitu Jalan Agus Salim, Jalan Mekarsari, dsb. Keadaan tersebut disebabkan oleh banyaknya kendaraan bermotor khusunya sepeda motor yang memulai aktivitas pergerakan dari dalam Kecamatan Bekasi Timur dan memenuhi ruas jalan sehingga menurunkan level pelayanan jalan-jalan tersebut. Padahal ruas jalan tersebut telah terdapat sarana angkutan kota berupa angkutan kota yang melayani kebutuhan transportasi di Kecamatan Bekasi Timur. 
Kecenderungan yang terjadi dalam memilih moda transportasi, masyarakat lebih memilih pada kendaraan yang mampu meminimumkan waktu dengan biaya yang murah [4]. Pada kenyatannya kendaraan angkutan kota lebih memenuhi kriteria tersebut namun pelayanan yang diberikan lebih rendah dibandingkan dengan kendaraan pribadi. Sehingga, penglaju lebih banyak memilih menggunakan sepeda motor karena dinilai lebih praktis.

Artikel ini membahas bagaimanan model probabilitas berdasarkan kondisi eksisting dan mengidentifikasi variabel atau atribut yang berpengaruh terhadap probabilitas moda angkutan kota

\section{A. Kajian Pustaka}

\section{METODE PENELITIAN}

Sebelum melakukan proses analisis, terlebih dahulu dilakukan kajian pustaka terkait pelayanan moda transportasi Tujuan dari kajian pustaka ini adalah untuk mengidentifikasi atribut atau variabel yang berpengaruh dalam faktor pemilihan moda yang dijadikan dasar oleh pelaku pergerakan dalam menentukan pilihan moda antara sepeda motor dan angkutan kota[5].

Tabel 1. Variabel Penelitian

\begin{tabular}{ll}
\hline \hline No. & Variabel \\
\hline \hline $\mathbf{1}$ & Keamanan Angkutan Kota \\
\hline $\mathbf{2}$ & Waktu Tunggu \\
\hline $\mathbf{3}$ & Waktu Tempuh \\
\hline $\mathbf{4}$ & Kenyamanan Angkutan Kota \\
\hline $\mathbf{5}$ & Biaya Transportasi \\
\hline \hline & Sumber : Hasil Analisis, 2015
\end{tabular}

\section{B. Metode Pengumpulan Data}

Data yang digunakan penelitian ini dilakukan dengan metode kuisioner guna menilai atau mengidentifikasi setiap nilai pada variabel yang digunakan. Objek dari kuisioner ini merupakan pelaku pergerakan yang tinggal dan memulai aktifitas di Kecamatan Bekasi Timur sehingga pengambilan data melalui kuisioner ini menggunakan metode home based interview. Penentuan sampel menggunakan rumus Slovin dengan jumlah populasi merupakan jumlah Kepala Keluarga(KK) di Kecamatan Bekasi Timur yang kemudian dibobotkan berdasarkan jumlah KK per kelurahan. Hasil dari bobot tersebut kemudian dikalikan dengan share eksisting penggunaan dengan asumsi $24 \%$ pengguna angkutan kota dan $76 \%$ pengguna sepeda motor.

Tabel 2. Jumlah Sampel

\begin{tabular}{ccccc}
\hline \hline Kelurahan & $\begin{array}{c}\text { Jumlah } \\
\text { KK }\end{array}$ & $\begin{array}{c}\text { Jumlah } \\
\text { Sampel } \\
\text { KK }\end{array}$ & $\begin{array}{c}\text { Sampel } \\
\text { Sepeda } \\
\text { Motor }\end{array}$ & $\begin{array}{c}\text { Sampel } \\
\text { Angkutan } \\
\text { Kota }\end{array}$ \\
\hline \hline Margahayu & 14540 & 27 & 21 & 6 \\
\hline Bekasi Jaya & 14230 & 25 & 17 & 8 \\
\hline Duren Jaya & 14135 & 25 & 19 & 6 \\
\hline Aren Jaya & 13762 & 23 & 19 & 4 \\
\hline Total & $\mathbf{5 6 6 6 7}$ & $\mathbf{1 0 0}$ & $\mathbf{7 6}$ & $\mathbf{2 4}$ \\
\hline
\end{tabular}

Sumber : Hasil Analisis, 2015

\section{HASIL DAN PEMBAHASAN}

\section{A. Gambaran Umum Wilayah Penelitian}

Kecamatan Bekasi Timur secara geografis terletak di bagian Timur Kota Bekasi. Dilihat dari kondisi alamnya adalah berupa dataran dengan luas wilayah $12,78 \mathrm{~km} 2$. Dibandingkan dengan kecamatan lainnya, Kecamatan Bekasi Timur ini adalah kecamatan yang mempunyai luas paling kecil tapi terpadat penduduknya, yaitu mencapai $18.603 \mathrm{jiwa} / \mathrm{km} 2$

Batas wilayah Kecamatan Bekasi Timur adalah:

a. Sebelah Utara : Berbatasan dengan Kecamatan Bekasi Utara

b. Sebelah Selatan : Berbatasan dengan Kecamatan Rawalumbu

c. Sebelah Barat : Berbatasan dengan Kecamatan Bekasi Selatan

d. Sebelah Timur : Berbatasan dengan Kabupaten Bekasi

\section{B. Hasil dan Pembahasan}

\section{Identifikasi Biaya Transportasi}

Angkutan kota di wilayah penelitian memiliki pengaturan tarif yang tetap dengan besaran biaya per $3 \mathrm{Km}$ adalah Rp. 3000 rupiah. Maka jika dibagi dengan jarak tersebut maka angkutan kota di wilayah penelitian memiliki tarif sebesar Rp. 1000/km

Menurut data yang diterima dari responden, rata-rata pengeluaran biaya khusus untuk sepeda motor berkisar RP.50.000 - Rp. 150.000 perbulan untuk biaya perawatan dan Rp. 2500 - Rp. 10.000 per hari untuk penggunaan bahan bakar dengan jarak tempuh responden yang bervariasi. Jika biaya total tersebut dibagi menjadi pengeluaran sepeda motor per hari, maka rentan biaya pengeluaran sepeda motor berkisar antara Rp. 900 sampai dengan Rp. 1200 per harinya.

\section{Identifikasi Waktu Moda}

Angkutan kota di wilayah penelitian memiliki rata-rata waktu tempuh yaitu 6 menit /Km yang didasari oleh data dari responden pengguna angkutan kota. Sedangkan rata-rata waktu tunggu angkutan kota yang diungkapkan oleh masing-masing reponden berkisar 10-15 menit.

Moda sepeda motor tidak memiliki waktu tunggu karena moda sudah tersedia setiap saat. Selain itu sepeda motor juga memiliki waktu tempuh yang lebih kecil dibandingkan angkutan kota. Berdasarkan data dari responden pengguna sepeda motor, sepeda motor memiliki rata-rata waktu tempuh sebesar 6 menit/km

\section{Identifikasi Persepsi Kenyamanan Angkot}

Dari total 100 responden pelaku pergerakan baik pengguna angkutan kota maupun pengguna sepeda motor, didapatkan pandangan responden terhadap kualitas kenyamanan angkutan kota saat ini.

Tabel 3. Persepsi Kenyamanan Angkutan Kota

\begin{tabular}{|c|c|}
\hline "Kenyamanan Angkutan Kota & Frekuensi \\
\hline Sangat Buruk & 12 \\
\hline Buruk & 38 \\
\hline Cukup & 37 \\
\hline Baik & 12 \\
\hline Sangat Baik & 1 \\
\hline Total & 100 \\
\hline
\end{tabular}

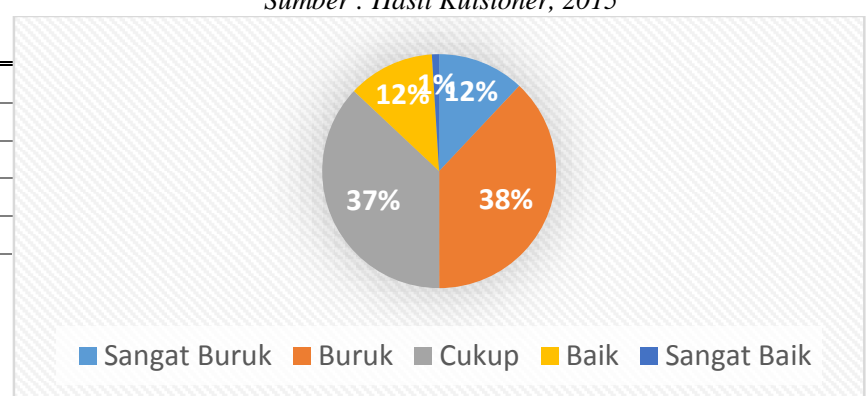

Gambar 1. Penilaian Responden Terhadap Kenyamanan Angkutan Kota Di Kecamatan Bekasi Timur Sumber : Hasil Kuisioner, 2015 


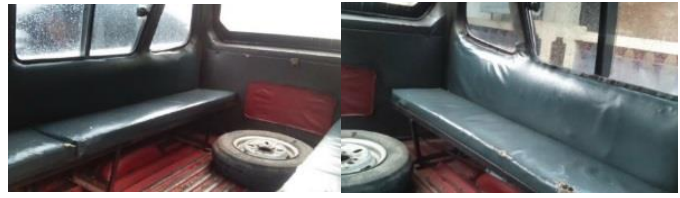

Gambar 2. Kondisi Kursi Penumpang Angkutan Kota Sumber : Survei Primer, 2015

Berdasarkan gambar diatas terlihat bahwa kondisi angkutan kota masih belum bisa memberikan taraf kenyamanan yang baik bagi pengguna sebagai pelaku pergerakan. Kondisi kursi yang terkesan seadanya untuk penumpang dan penempatan suku cadang yang tidak pada tempatnya pada angkutan kota menurunkan tingkat kenyamanan bagi penumpang.

\section{Identifikasi Persepsi Keamanan Angkot}

Dari total 100 responden pelaku pergerakan baik pengguna angkutan kota maupun pengguna sepeda motor, didapatkan pandangan responden terhadap kualitas keandalan angkutan kota saat ini.

\begin{tabular}{|c|c|}
\hline Keamanan Angkutan Kota & Frekuensi \\
\hline Sangat Buruk & 3 \\
\hline Buruk & 51 \\
\hline Cukup & 41 \\
\hline Baik & 4 \\
\hline Sangat Baik & 1 \\
\hline Total & 100 \\
\hline
\end{tabular}

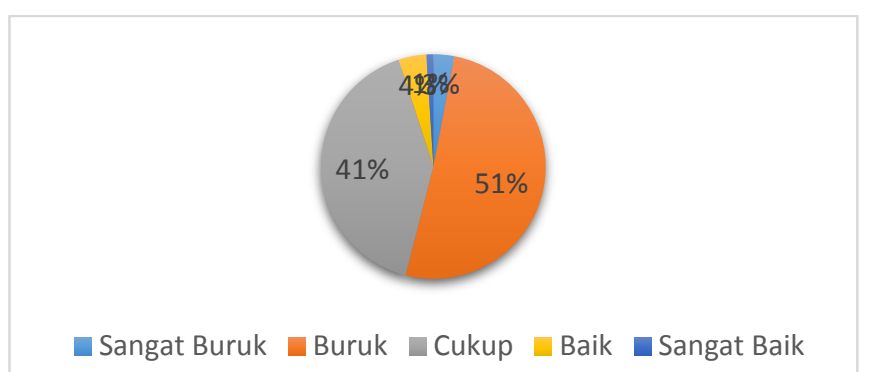

Gambar 3. Penilaian Responden Terhadap Keamanan Angkutan Kota Sumber : Hasil Kuisioner, 2015

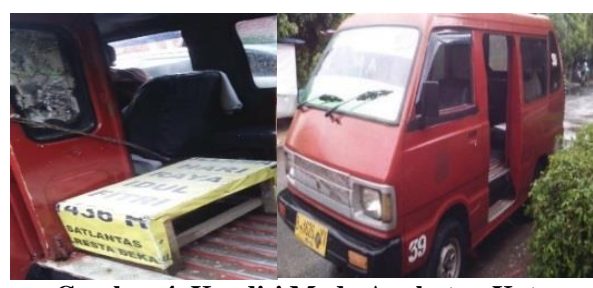

Gambar 4. Kondisi Moda Angkutan Kota Sumber : Survey Primer, 2015

Gambar diatas menjelaskan bagaimana kondisi keamanan moda angkutan kota di Kecamatan Bekasi Timur. Masih adanya pemanfaatan kursi di dekat pintu tanpa adanya pengamanan seperti tiang genggaman. Selain itu, tidak berfungsinya tuas pintu sisi pengemudi dan jendela juga semakin memperburuk keamanan angkutan kota yang membuat pengguna angkutan kota dengan mudahnya menjadi target tindak kejahatan.

\section{Persamaan Fungsi Utilitas Moda}

Perbedaan nilai guna dari suatu moda merupakan pola yang dibentuk dari individu pelaku pergerakan dalam memilih moda. Hal ini membentuk fungsi utilitas bagi masing-masing moda yang selanjutnya akan dihitung bagaimana kemungkinan pergeseran pengguna moda sepeda motor ke angkutan kota melalui uji sensitivitas perubahan nilai atribut. Dalam menentukan model utilitas dari masing-masing moda, perlu dilakukan uji statistik untuk mengetahui apakah model yang didapat berpengaruh secara signifikan atau tidak dengan melihat dari beberapa poin. Atribut yang digunakan dalam pembentukkan model adalah biaya total,waktu total, persepsi kenyamanan angkutan kota dan persepsi keamanan angkutan kota. Biaya total yang dimaksudkan dalam penelitian ini adalah biaya yang diperlukan individu untuk memenuhi kebutuhan pergerakannya di penggunaan masing-masing moda. Biaya yang dimaksudkan adalah penggunaan BBM dan perawatan bagi pengguna sepeda motor serta tarif angkutan kota bagi pengguna jasa angkutan kota. Biaya angkutan kota yang ditetapkan bahwa biaya per $3 \mathrm{~km}$ sebesar Rp.3000 sehingga dapat diperoleh biaya per km angkutan kota sebesar Rp.1000. Khusus untuk pengguna sepeda motor, biaya perawatan moda perbulan akan dibagi 30 untuk menjadikan rata-rata biaya perawatan perhari yang kemudian di total dengan biaya BBM perhari.

Sedangkan parameter waktu total adalah waktu di dalam kendaraan dan waktu diluar kendaraan masing-masing moda. Dari total waktu dan total biaya tersebut akan dibagi oleh jarak termpuh total individu dalam melakukan perjalanan untuk mendapatkan biaya total per $\mathrm{Km}$ dan waktu total per $\mathrm{Km}$. Hal ini dilakukan guna menyamakan input data pada program SPSS per satuan jarak sehingga dapat diketahui biaya per jarak dan waktu tempuh per jarak. Untuk variabel lain yang bersifat kualitatif yaitu kenyamanan, dan keamanan angkutan kota dikonversikan menjadi nilai kuantitatif melalui metode suksesif interval dan dimasukkan kedalam model.

Tabel 5. Hasil Model Regressi

\begin{tabular}{ccccc}
\hline \hline Variabel & Nilai Koefisien & Wald & df & Sig. \\
\hline \hline Constant & 5.184 & 8.204 & 1 & 0.004 \\
\hline Waktu & -1.019 & 21.949 & 1 & 0.000 \\
\hline Kenyamanan & 0.901 & 4.034 & 1 & 0.045 \\
\hline Keamanan & 1.342 & 4.101 & 1 & 0.043 \\
\hline Biaya & 0.002 & 3.204 & 1 & 0.072 \\
\hline \multicolumn{6}{r}{ Sumber : Hasil Analisis SPSS, 2015 }
\end{tabular}

Selanjutnya nilai B dari analisis tersebut merupakan hasil untuk input pada rumus dasar utilitas sebagai berikut.

Umoda $=\beta o+\beta 1 X 1+\beta 2 X 2+\beta n X n$.

Dimana :

ßo: Konstanta model

$\beta$ : Koefisien variabel $n$

$\mathrm{Xn}$ :Nilai Atribut / variabel n

Model tersebut harus dilakukan beberapa uji terlebih dahulu untuk melihat nilai signifikasi model tersebut, apakah model tersebut signifikan atau tidak signifikan untuk diteruskan ke tahap selanjutnya. Berikut ini merupakan uji model tersebut.

\section{Uji Kesesuaian Model}

Dari hasil analisis tersebut diketahui bahwa nilai -2 Log likelihood paling maximum mendapatkan nilai sebesar 62,395 dengan enam kali tahap iterasi dibandingkan dengan nilai -2 Log likelihood pada iterasi sebelumnya sebesar 110,216. Dengan perbandingan nilai tersebut yang lebih kecil pada enam kali iterasi tersebut, maka model utilitas telah dianggap 
memenuhi prinsip maximum likelihood dan dinyatakan valid untuk dilanjutkan pada uji selanjutnya.

\section{Uji Simultan (Overall Test)}

Pada tahap ini model diuji secara keseluruhan untuk melihat apakah ada variabel yang berpengaruh terhadap model atau tidak dengan melihat nilai signifikansi. Uji ini memerlukan nilai signifikansi dari Omnibus test of model coefficient dibawah nilai signifikansi minimum 0,05 . Jika nilai signifikansi model dibawah 0,05 maka artinya model dinyatakan signifikan dengan terdapat variabel berpengaruh. Berikut merupakan output dari hasil analisis SPSS.

Tabel 6. Uji SImultan Melalui Omnibus Test

\begin{tabular}{|c|c|c|c|c|}
\hline & & Chi-square & df & Sig. \\
\hline \multirow{3}{*}{ Step 1} & Step & 47.821 & 4 & .000 \\
\hline & Block & 47.821 & 4 & .000 \\
\hline & Model & 47.821 & 4 & .000 \\
\hline
\end{tabular}

Dari hasil analisis tersebut diperoleh nilai signifikasi model sebesar 0,00 yang menjelaskan bahwa nilai signifikasi tersebut telah memenuhi standar signifikansi dengan nilai maksimum 0,05. Dengan demikian model tersebut dinyatakan signifikan.

\section{Uji Goodness of Fit}

Selain itu dilakukan uji Hosmer and Lemeshow Test untuk menguji kelayakan model regressi. Hipotesis dalam uji Hosmer and Lemeshow Test dapat dinyatakan sebagi berikut.

H0 : Model telah cukup menjelaskan data

H1 : Model tidak cukup menjelaskan data

Jika nilai Sig. > 0.05 maka model terima H0 atau model dinyatakan signifikan. Jika nilai Sig. $<0.05$ maka model tolak $\mathrm{H} 0$ atau dinyatakan tidak signifikan.

Dari hasil SPSS menjelaskan bahwa nilai Sig. dari Hosmer and Lemeshow Test sebesar 0.516 > dari nilai standar Sig. 0.05 yang artinya model tersebut dianggap signifikan dalam menjelaskan data.

\section{Uji Signifikansi Variabel}

Setelah model dinyatakan signifikan, maka perlu melihat signifikansi setiap variabel guna melihat apakah variabel tersebut signifikan dalam menjelaskan model atau tidak. Hasil SPSS perhitungan signifikansi model dapat dilihat pada tabel berikut.

\begin{tabular}{ccc}
\multicolumn{3}{c}{ Tabel 8. Uji Signifikansi Variabel } \\
\hline \hline Atribut & Koefisien & Sig. \\
\hline \hline Waktutotal & -1.019 & .000 \\
\hline Kenyamanan & .901 & .045 \\
\hline Keamanan & 1.342 & .043 \\
\hline Biaya & .002 & .072 \\
\hline Constant & 5.184 & .004 \\
\hline Sumber : Hasil Analisis SPSS, 2015 &
\end{tabular}

Dari hasil analisis SPSS tersebut diperoleh nilai signifikansi dari setiap variabel yaitu variabel Biaya atau biaya dengan nilai signifikansi sebesar 0,072 dan variabel Waktutotal atau waktu total perjalanan baik di dalam dan di luar kendaraan sebesar 0,00. Keempat nilai signifikansi memenuhi signifikansi dengan tingkat kepercayaan standar $90 \%$ dengan nilai error dibawah 0,10 .

\section{Uji Multikolinieritas Variabel}

Ketika hasi estimasi statistik (hasil regresi) telah didapatkan, tidak dengan sendirinya hasil ini bisa digunakan sebagai dasar pengambilan keputusan. Masalah multikolinearitas muncul jika terdapat hubungan yang sempurna atau pasti di antara satu atau lebih variabel independen dalam model. Berikut merupakan hasil nilai multikolinieritas dalam model utilitas yang didapatkan dari matriks korelasi berikut.

Tabel 9. Tabel Multikolinieritas

\begin{tabular}{lccccc}
\hline \hline & Constant & Waktu & Kenyamanan & Keamanan & Biaya \\
\hline \hline Constant & 1.000 & -.563 & -.420 & -.337 & .104 \\
\hline Waktu & -.563 & 1.000 & .275 & -.136 & -.584 \\
\hline $\begin{array}{l}\text { Kenyamana } \\
n\end{array}$ & -.420 & .275 & 1.000 & .483 & -.039 \\
\hline Keamanan & -.337 & -.136 & .483 & 1.000 & -.185 \\
\hline Biaya & .104 & -.584 & -.039 & -.185 & 1.000 \\
\hline \multicolumn{5}{c}{ Sumber $:$ Hasil Analisis SPSS, 2015} \\
\end{tabular}

Dari hasil matriks korelasi tersebut dapat diketahui nilai korelasi antar variabel tidak ada yang melebihi nilai 0.6 yang menjelaskan bahwa tidak ada nilai multikolinieritas antar variabel baik waktu, biaya, kenyamanan, dan keamanan sehingga varibel tersebut dapat menjelaskan model secara independen.

\section{Model Probabilitas Eksisting}

Nilai utilitas moda diperoleh dari hasil perkalian fungsi yang dikalikan dengan rata-rata baik rata-rata biaya total per hari per $\mathrm{km}$ maupun dengan waktu tempuh total per km yang kemudian dikalikan dengan rumus dasar probabilitas. Untuk persamaan probabilitas angkot eksisting dapat dilihat pada persamaan berikut.

Pangkot $=\frac{e^{\text {Uangkot }}}{e^{\text {Uangkot }}+e^{\text {Umotor }} .}$
Pangkot $=\frac{1}{1+e^{\text {(Umotor-Uangkot })}}$.

Dimana :

Pangkot : Probabilitas Angkot

Pmotor : Probabilitas Motor

Uangkot : Nilai Utilitas Angkot

Umotor : Nilai Utilitas Motor

Dari hasil analisis model dan setelah variabel dan model dinyatakan signifikan dan layak untuk dijadikan model utilitas, maka diperoleh persamaan utilitas sebagai berikut.

\section{$U_{\text {motor }}=$ 5, $184+$ 0, 002 Biaya $-1,019$ Waktutotal + 0,901 Kenyamanan $+1,342$ Keamanan.

Sedangkan untuk Utilitas angkutan kota adalah sebagai berikut.

\section{$U_{\text {angkot }}=$ 0, 002 Biaya - 1, 019 Waktutotal + 0,901 Kenyamanan $+1,342$ Keamanan.}

Nilai konstanta sebesar $\mathbf{5 , 1 8 4}$ adalah selisih antara nilai utilitas konstan antara sepeda motor dan angkutan kota berdasarkan variabel input yaitu waktu, biaya, kenyaman, dan keamanan. Nilai negative pada bobot variabel menjelaskan bahwa jika ada penambahan atribut dari variabel tersebut maka akan terjadi penurunan nilai guna pada moda yang bersangkutan. Sedangkan nilai positif pada bobot variabel menjelaskan bahwa setiap ada peningkatan nilai pada atribut tersebut, maka akan terjadi peningkatan nilai guna pada moda yang bersangkutan. 
Untuk dapat mengetahui nilai utilitas dari masing-masing moda, maka perlu diketahui nilai atribut dari variabel Biaya, Waktu total dan persepsi pengguna kedua moda terhadap kenyamanan dan keamanan angkutan kota sehingga diperoleh nilai utilitas dan probabilitas sebagai berikut.

Tabel 10. Nilai Rata-Rata Atribut dan Probabilitas Eksisting

\begin{tabular}{ccc}
\hline \hline & Sepeda Motor & Angkutan Kota \\
\hline \hline Biaya & Rp. $966 / \mathrm{Km}$ & Rp. $1000 / \mathrm{Km}$ \\
\hline Waktu & 6 Menit/Km & 9 Menit/Km \\
\hline $\begin{array}{c}\text { Persepsi } \\
\text { Kenyamanan }\end{array}$ & $3($ Cukup)* & 2 (Buruk)** \\
\hline $\begin{array}{c}\text { Persepsi } \\
\text { Keamanan }\end{array}$ & 3 (Cukup)* $^{*}$ & 2 (Buruk)** \\
\hline Utilitas & $\mathbf{7 . 7 3 1}$ & $\mathbf{- 2 . 6 8 5}$ \\
\hline Probabilitas & $\mathbf{0 . 9 9 9 9 7}$ & $\mathbf{0 . 0 0 0 0 3}$
\end{tabular}

* Asumsi nilai guna lebih yang lebih tinggi dibanding moda angkutan kota yang dibobotkan dengan metode MSI (Suksesif interval)

** Rata-rata persepsi masyarakat terhadap kualitas angkutan kota Sumber : Hasil Analisis, 2015

\section{Uji Sensitivitas Model}

Pengujian sensitivitas pada pembahasan ini menggunakan uji atribut dari sisi nilai utilitas angkutan kota, hal tersebut bertujuan untuk melihat pengaruh masing-masing atribut seperti keamanan, waktu, dan kenyamanan terhadap perubahan nilai probabilitas angkutan kota. Pengaruh tersebut menggambarkan seberapa sensitif perubahan satu nilai dari atribut mempengaruhi perubahan probabilitas angkutan kota yang dilihat dari seberapa besar bobot peubah yang dikalikan dengan nilai atribut dapat mengubah probabilitas moda angkutan kota. Masing-masing atribut tersebut memiliki bobot peubah dari yang mulai terbesar sampai terkecil sebagai berikut. Untuk atribut keamanan dan kenyamanan digunakan persepsi dari 76 orang pengguna motor terkait persepsi mereka terhadap pelayanan angkutan kota.

\section{Tabel 11. Bobot Atribut Moda}

\begin{tabular}{cc}
\hline \hline Atribut & Bobot \\
\hline \hline Keamanan & 1,342 \\
\hline Waktu & $-1,019$ \\
\hline Kenyamanan & 0,901 \\
\hline Biaya & 0,002 \\
\hline \hline Sumber : Hasil Analisis SPSS, 2015
\end{tabular}

a. Atribut Keamanan

Atribut keamanan merupakan variabel kualitatif, untuk dapat digunakan dalam model maka diperlukan perubahan sifat dari kualitatif menjadi kuantitatif menggunakan metode suksesif interval dengan bantuan Ms. Excel.

Tabel 12. Sensitivitas Atribut Keamanan

\begin{tabular}{cccc}
\hline \hline Tingkat Keamanan & Frekuensi & Nilai MSI & Pangkot(\%) \\
\hline \hline Sangat Buruk & 1 & 1,000 & 0.002 \\
\hline Buruk & 38 & 2,841 & 0.023 \\
\hline Cukup & 32 & 4,214 & 0.144 \\
\hline Baik & 4 & 5,360 & 0.665 \\
\hline Sangat Baik & 1 & 6,142 & 1.876 \\
\hline \hline \multicolumn{4}{c}{ Sumber : Hasil Analisis, 2015}
\end{tabular}

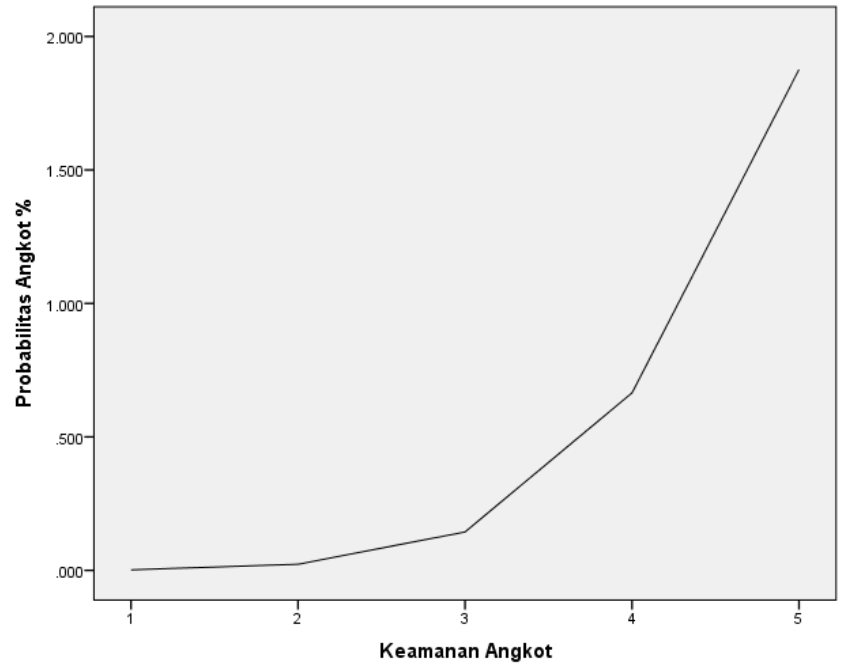

Gambar 5. Grafik Sensitivitas Atribut Keamanan Sumber : Hasil Analisis, 2015

Berdasarkan ilustrasi kurva pada tabel dan gambar diatas dapat diketahui bahwa peningkatan taraf keamanan angkutan kota dengan tidak merubah atribut lainnya dapat meningkatkan probabilitas angkutan kota secara signifikan

b. Atribut Waktu

Uji sensitivitas yang dilakukan adalah dengan mengubah waktu model angkutan kota dengan perubahan atau penurunan sebesar $1 \mathrm{menit} / \mathrm{km}$ dari waktu yang paling besar sampai ke waktu paling minimum dengan kondisi atribut lainnya tetap.

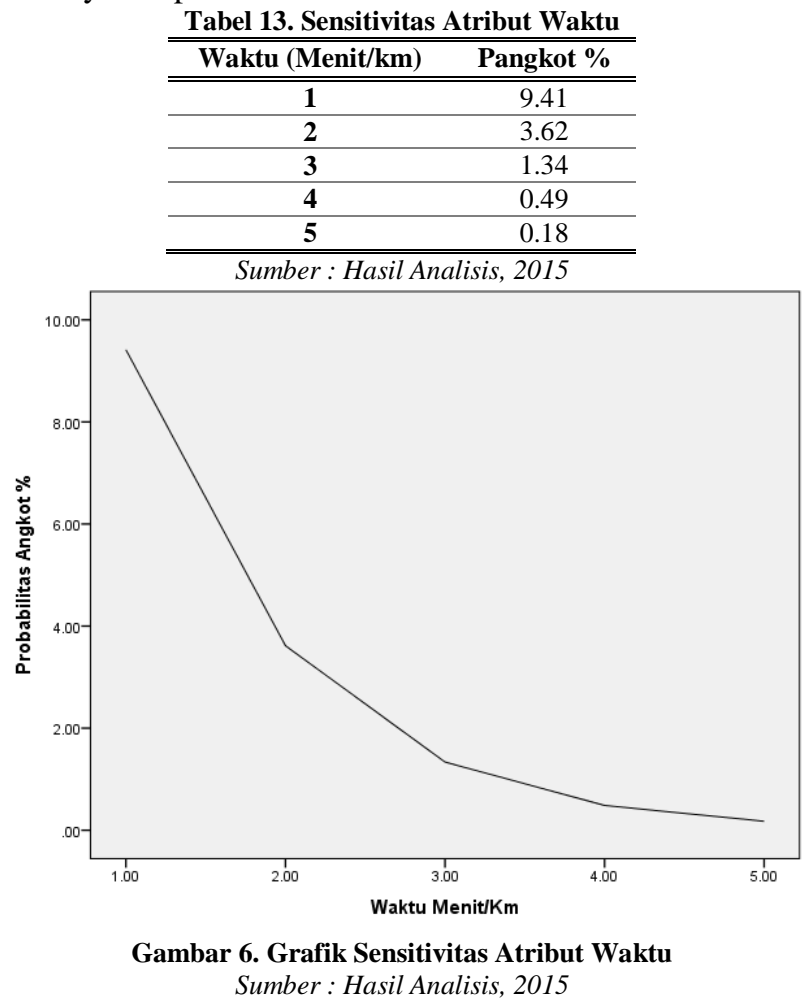

c. Atribut Kenyamanan

Sama halnya dengan atribut keamanan, atribut keamanan mengkonversikan nilai kualitatif menjadi kuantitatif menggunakan metode suksesif interval. 
Tabel 14. Sensitivitas Atribut Kenyamanan

\begin{tabular}{cccc}
\hline \hline $\begin{array}{c}\text { Tingkat } \\
\text { Kenyamanan }\end{array}$ & Frekuensi & Nilai MSI & $\begin{array}{c}\text { Pangkot } \\
(\boldsymbol{\%})\end{array}$ \\
\hline \hline Sangat Buruk & 9 & 1.000 & 0.0012 \\
\hline Buruk & 30 & 2.165 & 0.0035 \\
\hline Cukup & 28 & 3.218 & 0.0090 \\
\hline Baik & 8 & 4.235 & 0.0224 \\
\hline Sangat Baik & 1 & 5.244 & 0.0557 \\
\hline \multicolumn{4}{c}{ Sumber : Hasil Analisis, 2015} \\
\end{tabular}

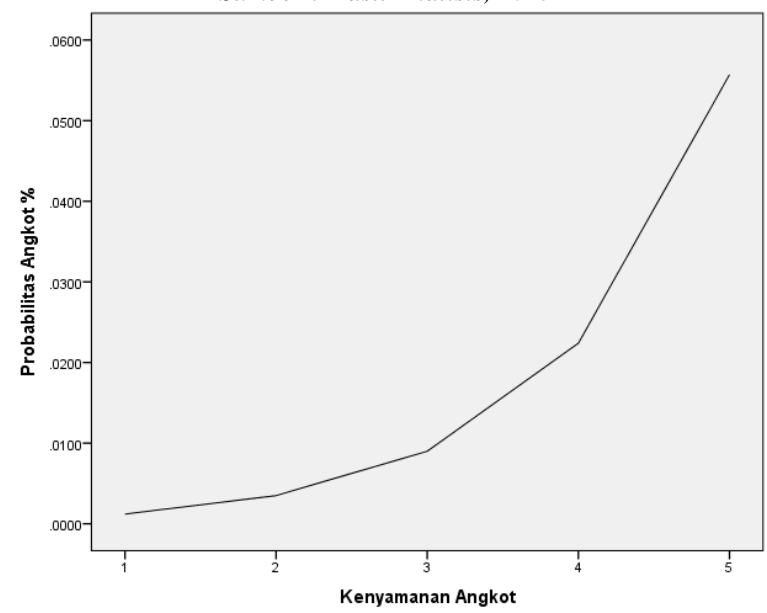

Gambar 7. Grafik Sensitivitas Atribut Kenyamanan Sumber : Hasil Analisis, 2015

d. Atribut Biaya

Simulasi sensitivitas berdasarkan atribut biaya menggunakan model utilitas angkutan kota, uji sensitivitas yang dilakukan adalah dengan mengubah biaya model angkutan kota $/ \mathrm{km}$ dengan perubahan atau penurunan sebesar Rp. 1/km dari biaya eksisting sampai ke biaya paling minimum.

\begin{tabular}{cc}
\multicolumn{2}{c}{ Tabel 15. Sensitivitas Atribut Biaya } \\
\hline \hline Biaya $(\mathbf{R p} / \mathbf{k m})$ & Pangkot $\%$ \\
\hline 1000 & 0.003 \\
\hline 999 & 0.003 \\
\hline 998 & 0.003 \\
\hline 997 & 0.003 \\
\hline 996 & 0.003 \\
\hline \hline Sumber : Hasil Analisis, 2015
\end{tabular}

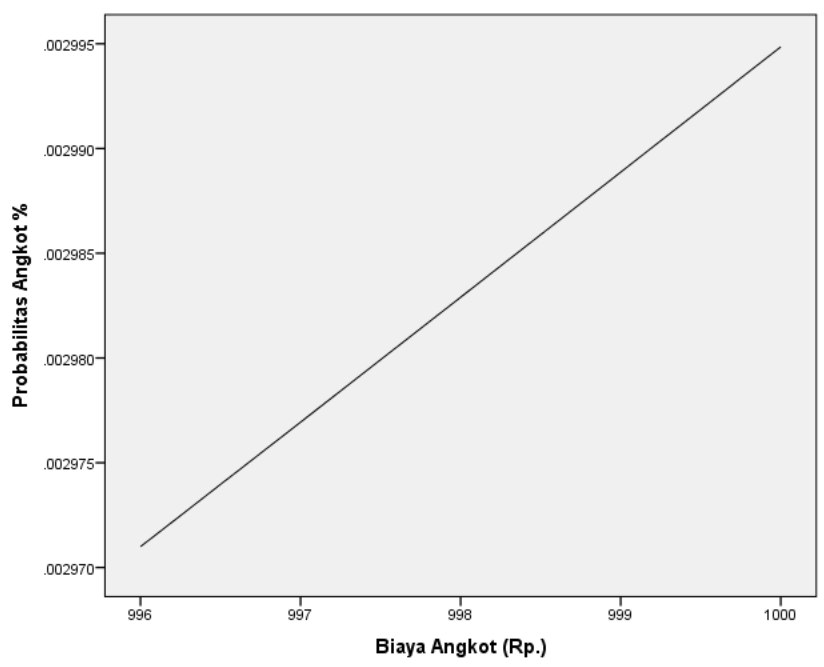

Gambar 8. Grafik Sensitivitas Atribut Biaya Sumber : Hasil Analisis, 2015
Berdasarkan pembahasan empat atribut diatas dapat diketahui bahwa probabilitas angkutan kota meningkat secara signifikan jika ada perbaikan atribut keamanan, waktu, dan keanyamanan angkutan kota. Namun, perbaikan atribut biaya tidak memberikan perubahan yang signifikan dalam peningkatan probabilitas angkutan kota.

\section{KESIMPULAN}

Perhitungan probabilitas eksisting antara moda sepeda motor dan angkutan kota menemukan bahwa probabilitas pemilihan moda angkutan kota masih sangat kecil yaitu sebesar $0.003 \%$ dibandingkan dengan nilai probabilitas eksisting sepeda motor sebesar 99.997\% Pembentukan model probabilitas pemilihan moda signifikan dipengaruhi oleh waktu, biaya, keamanan, kenyamanan.

a. Atribut keamanan memiliki nilai koefisien sebesar 1,342 dan signifikan berpengaruh terhadap perubahan probabilitas pilihan moda

b. Atribut waktu memiliki nilai koefisien sebesar -1,019 dan signifikan berpengaruh terhadap perubahan probabilitas pilihan moda

c. Atribut kenyamanan memiliki nilai koefisien sebesar 0,901 dan signifikan berpengaruh terhadap probabilitas pilihan moda

d. Atribut biaya memiliki nilai keofisien sebesar 0,002 dan tidak signifikan mempengaruhi perubahan probabilitas pilihan moda.

Peningkatan probabilitas pilihan moda angkutan kota dapat ditingkatkan dengan meningkatkan kualitas keamanan angkutan kota, waktu tunggu angkutan kota, waktu tempuh angkutan kota, dan keanyamanan angkutan kota.

\section{UCAPAN TERIMA KASIH}

Penulis G.P. mengucapkan terima kasih kepada Jurusan Perencanaan Wilayah dan Kota atas ilmu yang diberikan dari tahun 2011-2015. Penulis juga diperkenankan menyampaikan ucapan terima kasih kepada Dinas Perhubungan Kota Bekasi dan seluruh masyarakat di Kecamatan Bekasi Timur atas bantuannya dalam memberikan informasi sehingga penelitian ini dapat berjalan.

\section{DAFTAR PUSTAKA}

[1] Miro, Fidel.2005.Perencanaan Transportasi: Untuk Mahasiswa, Perencana, dan Praktisi. Jakarta: Erlangga

[2] Dinas Perhubungan Kota Bekasi. 2013. Tataran Transportasi Lokal Kota Bekasi Tahun 2013

[3] Badan Pusat Statistik Kota Bekasi. 2014. Kota Bekasi Dalam Angka 2014

[4] Warpani, Suwardjoko. 1990. Merencanakan Sistem Perangkutan. Bandung: Penerbit ITB

[5] Harries. 1976. State-of-the-art review of Urban Transportation Concepts and Public Attitudes. US Department of Transportation. Washington. 